\title{
Ion fluxes and hematological parameters of two teleosts from the Rio Negro, Amazon, exposed to hypoxia
}

\author{
Baldisserotto, B. ${ }^{\mathrm{*} *}$, Chippari-Gomes, AR. ${ }^{\mathrm{b}}$, Lopes, $N$. $^{\mathrm{c}}$, Bicudo, JEPW. ${ }^{\mathrm{d}}$, \\ Paula-Silva, MN. ${ }^{\mathrm{b}}$, Almeida-Val, VMF. ${ }^{\mathrm{b}}$ and Val, $A$. $^{\mathrm{b}}$ \\ ${ }^{a}$ Departamento de Fisiologia e Farmacologia, Universidade Federal de Santa Maria - UFSM, \\ Av. Roraima, s/n, CEP 97105-900, Santa Maria, RS, Brazil \\ 'Laboratório de Ecofisiologia e Evolução Molecular, Instituto Nacional de Pesquisas da Amazônia - INPA, \\ Av. André Araújo, 2936, CEP 69083-000, Manaus, AM, Brazil \\ ${ }^{\mathrm{c}}$ Centro Universitário do Norte - UNINORTE, \\ Av. Joaquim Nabuco, 1232, CEP 69000-000, Manaus, AM, Brazil \\ ${ }^{d}$ Departamento de Fisiologia do Instituto de Biociências, Universidade de São Paulo - USP, \\ Rua do Matão, Travessa 14, 321, CEP 05508-900, São Paulo, SP, Brazil \\ *e-mail: bernardo@smail.ufsm.br \\ Received June 19, 2006 - Accepted May 25, 2007 - Distributed August 31, 2008
}

(With 1 figure)

\begin{abstract}
The aim of this study was to describe the effect of hypoxia on whole body ion fluxes and hematological parameters in two Amazonian teleosts: Serrasalmus eigenmanni and Metynnis hypsauchen. The increase of $\mathrm{Na}^{+}$and $\mathrm{Cl}^{-}$effluxes on $M$. hypsauchen exposed to hypoxia may be related to an increase of gill ventilation and effective respiratory surface area, to avoid a reduction in the oxygen uptake, and/or with the decrease of $\mathrm{pHe}$, that could inhibit $\mathrm{Na}^{+}$and $\mathrm{Cl}^{-}$transporters and, therefore, reduce influx of these ions. Effluxes of $\mathrm{Na}^{+}$and $\mathrm{Cl}^{-}$were lower in hypoxia than in normoxia for S. eigenmanni, possibly because in hypoxia this species would reduce gill ventilation and oxygen uptake, which would lead to a decrease of gill ion efflux and, consequently, reducing ion loss. The increase on hematocrit (Ht) during hypoxia in M. hypsauchen probably was caused by an increase of the red blood cell volume (MCV). For S. eigenmanni the increase on glucose possibly results from the usage of glucose reserve mobilization. Metynnis hypsauchen showed to be more sensitive to hypoxia than Serrasalmus eigenmanni, since the first presented more significant alterations on these osmoregulatory and hematological parameters. Nevertheless, the alterations observed for both species are strategies adopted by fishes to preserve oxygen supply to metabolizing tissues during exposure to hypoxia.
\end{abstract}

Keywords: amazon fishes, dissolved oxygen levels, hematology, body ion fluxes.

\section{Fluxos iônicos e parâmetros hematológicos em duas espécies de teleósteos do Rio Negro, Amazônia, expostos à hipoxia}

\section{Resumo}

O objetivo deste trabalho foi descrever o efeito da hipoxia no fluxo iônico corporal e nos parâmetros hematológicos em duas espécies de teleósteos da Amazônia: Serrasalmus eigenmanni e Metynnis hypsauchen. O aumento dos efluxos de $\mathrm{Na}^{+} \mathrm{e} \mathrm{Cl}^{-}$em $M$. hypsauchen expostos à hipoxia pode estar relacionado ao aumento da ventilação branquial e da eficiência da área da superfície respiratória, a fim de evitar redução na captação de oxigênio; e/ou com a diminuição do pHe, que pode inibir os transportadores de $\mathrm{Na}^{+}$e $\mathrm{Cl}^{-}$e, então, reduzir o influxo destes íons. Os efluxos de $\mathrm{Na}^{+} \mathrm{e}$ $\mathrm{Cl}^{-}$foram menores em hipoxia do que em normoxia para a espécie $S$. eigenmanni, possivelmente porque esta espécie em hipoxia poderia reduzir a ventilação branquial e a captação de oxigênio, a qual levaria a uma diminuição do efluxo branquial de íons e, conseqüentemente, à redução da perda de íons. O aumento do hematócrito (Ht) durante hipoxia em M. hypsauchen provavelmente foi causado pelo aumento do volume das células vermelhas do sangue (MCV). Para a espécie S. eigenmanni, o aumento da glicose possivelmente foi resultado do uso da mobilização da reserva de glicose. A espécie Metynnis hypsauchen mostrou ser mais sensível à hipoxia do que a espécie Serrasalmus eigenmanni, uma vez que a primeira espécie apresentou mais alterações significativas em seus parâmetros osmorregulatórios e hematológicos. Contudo, as alterações observadas em ambas as espécies são estratégias adotadas pelos peixes a fim de preservar o suprimento de oxigênio para metabolização nos tecidos durante exposição à hipoxia.

Palavras-chave: peixes amazônicos, níveis de oxigênio dissolvido, hematologia, fluxo de íons corporal. 


\section{Introduction}

Amazonian waters present wider changes in dissolved oxygen than those observed in waters from temperate zones. Seasonal, daily, and spatial oscillations of several parameters (photosynthesis, organic decomposition, respiration of macrophytes and phytoplankton, temperature, etc.) occur in this environment and induce a complex pattern of oxygen distribution (Junk et al., 1983; Val, 1993; Almeida-Val et al., 1999). For example, in some lakes the oxygen concentrations can change from oversatured levels at noon to almost zero at night (Val, 1996). The Amazon freshwater ichthyofauna has representatives of several teleosts orders, and many species are adapted to low oxygen concentrations (Val and Almeida-Val, 1995). The main strategies to deal with hypoxic environment are the use of air-breathing (obligatory or facultative), aquatic surface respiration, and hypoxia tolerance mechanisms, including metabolic suppression (Almeida-Val and Farias, 1996; Almeida-Val et al., 1999).

Many adaptive adjustments in fishes may occur simultaneously to improve oxygen intake, such as increase in ventilatory volume and frequency and heart rate, alterations of enzyme levels in different tissues, alterations in plasma concentrations of metabolites (glucose and lactate), and changes in hematological parameters, levels of intraerytrocytic phosphates, and proportion of hemoglobin fractions (reviewed by Val and Almeida-Val, 1995; Almeida-Val et al., 2006; Brauner and Val, 2006). Val (1996) suggested that when these adjustments occur concomitantly they could be the result of the effect of catecholamines released during stress.

The waters of the Rio Negro drain nutrient-poor forest soils and are very dilute and acidic (Furch, 1984). Teleosts living in these waters exhibit exceptional acid tolerance, and studies on ion fluxes of some Amazonian species deal with the effect of low water $\mathrm{pH}$ and low calcium levels (Gonzalez et al., 1997; 1998; Wood et al., 1998). As far as we know, few studies have analyzed the effects of hypoxia on ion fluxes in Amazonian teleosts. The possible effects of hypoxia on ion fluxes include changes of osmoregulatory properties in the gills due to changes in blood flow (Sundin, 1999), changes in blood properties (Fernandes et al., 1999), and increase of $\mathrm{Na}^{+}$ loss (Gonzalez and McDonald, 1992; 1994). The present study describes the effect of hypoxia on whole body ion fluxes and hematological parameters in two Amazonian teleosts: Serrasalmus eigenmanni (black piranha) and Metynnis hypsauchen (pacu).

\section{Material and Methods}

Specimens of Serrasalmus eigenmanni Norman, 1929 (50-150 g) and Metynnis hypsauchen (Müller and Troschel, 1844) (60-120 g) (Serrasalmidae) were collected with drift nets from Rio Negro, at Anavilhanas Archipelago, Amazon, Brazil. Fish were kept outdoors without feeding in a running $1000 \mathrm{~L}$ freshwater tank $\left(27-28^{\circ} \mathrm{C}\right)$ for at least 24 hours. Measured water composition was (in $\mu \mathrm{M} . \mathrm{L}^{-1}$ ): $\mathrm{Na}^{+}, 12.3 ; \mathrm{Cl}^{-}, 34.9 ; \mathrm{pH} 6.37$.

After acclimation fish were placed in individual chambers $(850 \mathrm{~mL})$ served with a flow of $110 \mathrm{~mL} / \mathrm{min}$ of recirculated water. The fish chambers were housed on a wet table that drained water back into the recirculation reservoir. Total volume of the system, serving a maximum of 4 fish, was $50 \mathrm{~L}$. This flow of water was kept for 1 hour and then the chambers were operated as closed systems for 240 minutes. Water samples $(5 \mathrm{~mL})$ were taken at the beginning and end of this period for $\mathrm{Na}^{+}$, $\mathrm{Cl}^{-}$and $\mathrm{pH}$ analysis. $\mathrm{Na}^{+}$concentrations were measured with a B262 flame photometer (Micronal), and $\mathrm{Cl}^{-}$concentrations were measured by the colorimetric assay as described by Zall et al. (1956). Water $\mathrm{pH}$ was determined with pH meter DMPH-2 (Digimed, São Paulo, Brazil). Ion fluxes were calculated according to Gonzalez et al. (1998).

Dissolved oxygen levels in the chambers were measured each hour with an acid-base digital analyzer, connected to a "Radiometer" (PHM72-Mk2). One group of $M$. hypsauchen was maintained in the range of 110-130 $\mathrm{mmHg}$ throughout the experiment (normoxia group), while another group was exposed to $70-85 \mathrm{mmHg}$ oxygen levels (hypoxia group). The dissolved oxygen levels were initially reduced within 15 minutes by bubbling $\mathrm{N}_{2}$ in the water. Reduced aeration kept oxygen levels within the described range during the experiments. Exposure of this species to lower oxygen levels $(40-60 \mathrm{mmHg})$ resulted in the death of most specimens in 2 hours. For S. eigenmanni, the dissolved oxygen levels were $110-135 \mathrm{mmHg}$ and $55-70 \mathrm{mmHg}$ for normoxic and hypoxic groups, respectively.

At the end of both series of experiments blood samples were collected from the caudal vein into heparinized syringes. Hematocrit values $(\mathrm{Ht} \%)$ were determined after 10 minutes centrifugation in micro-haematocrit tubes. Hemoglobin concentration ([Hb] mg.dL ${ }^{-1}$ ) was measured as described by Kampen and Zijlstra (1964). Red blood cell counts (RBC) were obtained with the use of a Neubauer chamber. Mean corpuscular volume (MCV), mean corpuscular hemoglobin concentration (MCHC), and mean corpuscular hemoglobin $(\mathrm{MCH})$ were determined according to Brown (1976). Plasma glucose levels were estimated using commercial kits (Doles S.A.). Plasma $\mathrm{pH}(\mathrm{pHe})$ was measured using a glass microcapillary electrode (G229, Radiometer, Copenhagen) coupled to a PHM-73 pH meter. Radiometer precision buffers were used to calibrate the electrode.

Net ion fluxes and hematological parameters of fish groups exposed normoxia and hypoxia groups were compared by Student's two-tailed $t$-test (data with normal distribution) or by Mann-Whitney test (data with non-normal distribution) with the aid of the GraphPad Instat program (version 2.05a). Data are expressed as mean \pm SEM, and the minimum significance level was $\mathrm{P}<0.05$. 


\section{Results}

Specimens of $M$. hypsauchen presented an influx of $\mathrm{Na}^{+}$and $\mathrm{Cl}^{-}$in normoxia. Exposure to hypoxia induced an efflux of both ions in this species. However, S. eigenmanni normoxic groups showed $\mathrm{Na}^{+}$and $\mathrm{Cl}^{-}$effluxes (mainly $\mathrm{Cl}^{-}$), which were reduced in specimens exposed to hypoxia (Figure 1). Water $\mathrm{pH}$ in the chambers at the end of the experiment was $6.56 \pm 0.05$ for both species.

Exposure of $M$. hypsauchen to moderate hypoxia led to an increase of hematocrit and MCV values, while MCHC and extracellular $\mathrm{pH}(\mathrm{pHe})$ decreased. Other blood parameters were not affected by hypoxia. On the other hand, moderate hypoxia induced increase on plasma glucose and reduction on MCHC values of $S$. eigenmanni. Other blood parameters remained unchanged in this species (Table 1).

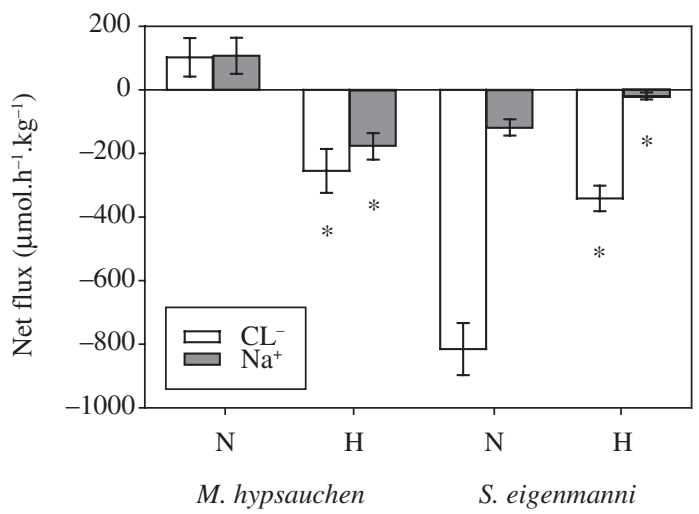

Figure 1. Net $\mathrm{Na}^{+}$and $\mathrm{Cl}^{-}$fluxes of Metynnis hypsauchen and Serrasalmus eigenmanni maintained in normoxia $(\mathrm{N})$ and hipoxia (H). Asterisks indicate significant difference of fluxes by Student's two-tailed $t$-test or Mann-Whitney test $(\mathrm{P}<0.05)$ at normoxia.

\section{Discussion}

Osmoregulation and gas exchange are the two most important roles of the gills in fish. Freshwater teleosts must balance the improvement of $\mathrm{O}_{2}$ diffusion at the gills with the osmoregulatory disadvantage that result from the ion loss and water influx increases (Perry and McDonald, 1993). The so called oxygen conformers decrease their oxygen demand and reduce ventilation when exposed to hypoxia. On the other hand, other species, called oxygen regulators, increase gill ventilation to keep $\mathrm{O}_{2}$ consumption constant under hypoxia until a critical oxygen level occurs, at which the respiration modes changes from regulating to conforming (Fernandes et al., 1999). Hypoxia also stimulates chemoreceptors in the gills (Milsom et al., 1999) and catecholamine release (Reid and Perry, 2003), promoting reflex changes in the branchial vasculature, elevating blood pressure in the branchial perfusion and an increase in the lamellar flux, which induces an increase of the effective respiratory surface area (Sundin, 1999). This circulatory change probably distorts and widens gill tight junctions, and consequently they become more permeable to ions (Gonzalez and McDonald, 1992; 1994).

Specimens of $M$. hypsauchen exposed to hypoxia presented an increase of $\mathrm{Na}^{+}$and $\mathrm{Cl}^{-}$effluxes. The same was observed in silver catfish, Rhamdia quelen (Quoy and Gaimard, 1824) exposed to hypoxic levels (around $55 \mathrm{mmHg}$ ) for the same time. However, effluxes in $R$. quelen maintained in hypoxia decreased as time went by (Rosso et al., 2006). Two explanations are possible: when exposed to hypoxia, M. hypsauchen would increase gill ventilation and effective respiratory surface area to avoid a reduction in the oxygen uptake. These changes would lead to an increase of the diffusional gradient resulting in ion loss across the gills. Studies with several teleosts species showed that there is an increase in $\mathrm{Na}^{+}$efflux whenever oxygen uptake increases (Gonzalez and McDonald, 1992; 1994). In addition,

Table 1. Blood parameters of Metynnis hypsauchen and Serrasalmus eigenmanni exposed to normoxia and hypoxia. Data are expressed as mean \pm SEM, numbers of individuals are indicated in branches. Asterisks indicate significantly difference from normoxia values by Student's two-tailed $t$-test $(\mathrm{P}<0.05)$.

\begin{tabular}{|c|c|c|c|c|}
\hline \multirow[t]{2}{*}{ Parameters } & \multicolumn{2}{|c|}{ Metynnis hypsauchen } & \multicolumn{2}{|c|}{ Serrasalmus eigenmanni } \\
\hline & Normoxia & Hypoxia & Normoxia & Hypoxia \\
\hline & $(100-130 \mathrm{mmHg})$ & $(65-95 \mathrm{mmHg})$ & $(100-150 \mathrm{mmHg})$ & $(55-90 \mathrm{mmHg})$ \\
\hline glucose $\left(\mathrm{mg} \cdot \mathrm{dL}^{-1}\right)$ & $81.54 \pm 21.39(5)$ & $69.73 \pm 12.72(6)$ & $38.91 \pm 15.47(6)$ & $52.39 \pm 12.54(4)^{*}$ \\
\hline hemoglobin (g.dL $\left.{ }^{-1}\right)$ & $6.35 \pm 0.43(6)$ & $5.85 \pm 0.31(6)$ & $8.43 \pm 0.62(7)$ & $7.49 \pm 0.37$ (4) \\
\hline hematocrit (\%) & $28.00 \pm 1.71(6)$ & $34.90 \pm 2.30(5)^{*}$ & $29.29 \pm 2.53(7)$ & $30.80 \pm 0.90$ \\
\hline $\mathrm{RBC}(\mathrm{x} 106 \mathrm{~mm} 3)$ & $2.12 \pm 0.24(6)$ & $1.73 \pm 0.19(6)$ & $2.03 \pm 0.18(7)$ & $2.00 \pm 0.20$ \\
\hline $\mathrm{MCV}(\mu \mathrm{m} 3)$ & $138.68 \pm 13.51(6)$ & $198.17 \pm 18.85(6)^{*}$ & $136.98 \pm 7.87(9)$ & $159.52 \pm 11.57(4)$ \\
\hline $\mathrm{MCH}(\mathrm{pg})$ & $31.38 \pm 3.32(6)$ & $35.16 \pm 3.07(6)$ & $29.36 \pm 1.61(10)$ & $24.60 \pm 1.77(5)$ \\
\hline $\mathrm{MCHC}(\%)$ & $22.66 \pm 0.63(6)$ & $17.84 \pm 0.47(4)^{*}$ & $46.91 \pm 3.91(9)$ & $29.04 \pm 1.13(4) *$ \\
\hline $\mathrm{pHe}$ & $7.57 \pm 0.07(5)$ & $7.06 \pm 0.0 .08(12)^{*}$ & $7.37 \pm 0.06(10)$ & $7.26 \pm 0.14(4)$ \\
\hline
\end{tabular}


an increase of lamellar flux due to hypoxia could also contribute to increase ion gill permeability. Another explanation, which does not exclude the previous one, is that the decrease of $\mathrm{pHe}$ of $M$. hypsauchen, induced by hypoxia, inhibited $\mathrm{Na}^{+}$and $\mathrm{Cl}^{-}$transporters and, therefore, reduced the influx of these ions. A decrease (compared with control at $\mathrm{pH}$ 7.8) of short-circuit current and transepithelial potential difference values was observed in the "in vitro" stripped intestine of freshwater-adapted Anguilla anguilla (Linnaeus, 1758) submitted to $\mathrm{pH} 7.0$, indicating an inhibition of ion transporters in this organ (Baldisserotto and Mimura, 1995). A similar effect could occur in the gills of $M$. hypsauchen. In addition, as hypoxia itself inhibited ion transporters in fish erythrocytes and hepatocytes (Nikinmaa, 2002), ion influx by osmoregulatory organs might also be affected.

However, S. eigenmanni in normoxia presented higher $\mathrm{Na}^{+}$and $\mathrm{Cl}^{-}$effluxes than in hypoxia. A possible explanation is that this species would adopt a different strategy from $M$. hypsauchen. When submitted to hypoxia, S. eigenmanni would reduce gill ventilation and oxygen uptake, which would lead to a decrease of gill ion efflux and, consequently, reducing ion loss, as observed. For example, a significant decrease on gill ventilation (compared to specimens maintained in normoxia) was observed in Nile tilapia, Oreochromis mossambicus, (Peters, 1852) exposed to hypoxic levels (below $20 \mathrm{mmHg}$ ) (Xu et al., 2006).

During hypoxia events, fishes use various strategies to cope with adverse condition. One of these strategies is the regulation of hematocrit and hemoglobin levels, as observed in the characiform Colossoma macropomum (Cuvier, 1816) (tambaqui) (Val, 1996). M. hypsauchen also showed significant increase of hematocrit, but probably this increase was not induced by spleen contraction as observed in tambaqui, since hemoglobin concentration did not increase. It is possible that the alteration of hematocrit was caused by an increase of the red blood cell volume (MCV). For S. eigenmanni, no relevant alteration was observed on hematological parameters, except by the increase on glucose levels. This increase can indicate that glucose was used as energy supply. According Almeida-Val et al. (2006), most Amazonian fish species subjected to some level of oxygen depletion showed alterations in plasma glucose and lactate levels resulting from the usage of glucose reserve mobilization, as probably occur with $S$. eigenmanni. The Amazon cichlid, Astronotus crassipinnis (Heckel, 1840), also presented accumulation of plasma glucose at low oxygen levels, probably due to an activation of hepatic glycogenolysis as indicated by the decrease in liver glycogen (Chippari-Gomes et al., 2005). The use of carbohydrate reserves such as glycogen or amino acids, which are the main fuels available for fermentation in animals, is almost always necessary (Hochachka and Somero, 2002). Glucose mobilization may occur even in facultative air breathers such as the armored catfish Pterygoplichthys gibbiceps (Kner, 1854), which is not necessarily related to anaerobic metabolism activation, since lactate levels are significantly decreased (Lopes, 2003). The reliance on extracellular glucose as a metabolic fuel under oxygen limitations may constitute one of the strategies to better deal with oxygen limitation and may occur in addition to other responses, and it may be dependent upon respiratory pattern and species phylogeny (Almeida-Val et al., 2006).

\section{Conclusions}

Metynnis hypsauchen showed to be more sensitive to hypoxia than Serrasalmus eigenmanni, since the first presented more significant alterations on these osmoregulation and hematological parameters. Nevertheless, the alterations observed on the metabolism of both species studied in this work are some of the myriad strategies adopted by fishes in order to preserve oxygen supply to metabolizing tissues during exposure to hypoxia (natural or experimental, for short or long term). Future studies of the effect of hypoxia on oxygen consumption and metabolism of the studied species will be necessary for better understanding of the obtained results.

Acknowledgements - The present work was supported by an internal grant from the National Institute for Research in the Amazon (INPA grant number 1-3140).

\section{References}

ALMEIDA-VAL, VMF. and FARIAS, IP., 1996. Respiration in fish of the Amazon metabolic adjustments to chronic hypoxia. In: Val, AL., Almeida-Val, VMF. and Randall, DJ. (Eds.). Physiology and Biochemistry of the Fishes of the Amazon. Manaus: INPA, p. 257-271.

ALMEIDA-VAL, VM., CHIPPARI-GOMES, AR. and LOPES, NP., 2006. Metabolic and physiological adjustments to low oxygen and high temperature in fishes of the Amazon. In Val, AL., Almeida-Val, VMF. and Randall, DJ. (Eds.). Fish Physiology. Heildelberg: Elsevier. p. 443-500, v. 21.

ALMEIDA-VAL, VMF., VAL, AL. and WALKER, I., 1999. Long and short-term adaptation of Amazon fishes to varying $\mathrm{O}_{2}$-levels: intra-specific phenotypic plasticity and interspecific variation. In Val, AL. and Almeida-Val, VMF. (Eds.). Biology of Tropical Fishes. Manaus: INPA. p. 185-206.

BALDISSEROTTO, B. and MIMURA, OM., 1995. Effect of $\mathrm{HCO}_{3}^{-}$and $\mathrm{pH}$ on ion transport in the posterior intestine of the freshwater-adapted teleost Anguilla anguilla. Braz. J. Med. Biol. Res., vol. 28, no.3, p. 327-330.

BRAUNER, CJ. and VAL, AL., 2006. Oxygen transfer. In Val, AL., Almeida-Val, VMF. and Randall, DJ. (Eds.). Fish Physiology. Heildelberg: Elsevier. p. 277-306, v. 21.

BROWN, BA., 1976. Hematology: principles and procedures. Philadelphia: Lea and Febiger.

CHIPPARI-GOMES, AR., GOMES, LC., LOPES, NP., VAL, AL. and ALMEIDA-VAL, VMF., 2005. Metabolic adjustments in two Amazonian cichlids exposed to hypoxia and anoxia. Comp. Biochem. Physiol., B, vol. 141, no. 3, p. 347-355. 
FERNANDES, MN., SANCHES, JR., MATSUZAKI, M., PANEPUCCI, L. and RANTIN, FT., 1999. Aquatic respiration in facultative air-breathing fish: effects of temperature and hypoxia. In Val, AL. and Almeida-Val, VMF. (Eds.). Biology of Tropical Fishes. Manaus: INPA. p. 341-352

FURCH, K., 1984. Water chemistry of the Amazon basin: the distribution of chemical elements among freshwaters. In Sioli, H. (Ed.). The Amazon: Limnology and Landscape Ecology of a Mighty Tropical River and Its basin. Dordrecht: Junk. p. 167-199.

GONZALEZ, RJ. and MCDONALD, DG., 1992. The relationship between oxygen consumption and ion loss in a freshwater fish. J. Exp. Biol., vol. 163, no.1, p. 317-332.

-, 1994. The relationship between oxygen uptake and ion loss in fish from diverse habitats. J. Exp. Biol., vol. 190, no. 1, p. $95-108$.

GONZALEZ, RJ., DALTON, VM. and PATRICK, ML., 1997. Ion regulation in ion-poor acidic water by the blackskirt tetra (Gymnocorymbus ternetzi), a fish native to the Amazon river. Physiol. Zool., vol. 70, no. 4, p. 428-435.

GONZALEZ, RJ., WOOD, CM., WILSON, RW., PATRICK, ML., BERGMAN, HL., NARAHARA, A. and VAL, AL., 1998. Effects of water $\mathrm{pH}$ and $\mathrm{Ca}^{+2}$ concentrations on ion balance in fish of the Rio Negro. Amazon. Physiol. Zool., vol. 71, no. 1, p. 15-22.

HOCHACHKA, PW. and SOMERO, GN., 2002. Biochemical Adaptation. Mechanism and Process in Physiological Evolution. New York: Oxford University Press.

JUNK, WJ., SOARES, GM. and CARVALHO, FM., 1983. Distribution of fish species in a lake of the Amazon river floodplain near Manaus (Lago Camaleão), with special reference to extreme oxygen conditions. Amazoniana, vol. 7, no. 4, p. 39-431.

KAMPEN, EJ. and ZIJLSTRA, WG., 1964. Standartization of haemoglobinometry. In Boroviczény, CG. (Ed.). Erythrocytometric methods and their standardizations. Lisbon: Transactions of the Standardizing Committee and Proceedings of Symposium 18 of the 9th Congress of the European Society of Haematology.
LOPES, NP. 2003. Ajustes metabólicos em sete espécies de Siluriformes sob condições hipóxicas: aspectos adaptativos. Manaus: Instituto Nacional de Pesquisas da Amazônia; Universidade Federal do Amazonas, Biologia de Água Doce e Pesca Interior, 168 p. [PhD Thesis].

MILSOM, WK., SUNDIN, L., REID, S., KALININ, A. and RANTIN. FT., 1999. Chemoreceptor control of cardiovascular reflexes. In Val, AL. and Almeida-Val, VMF. (Eds.). Biology of Tropical Fishes. Manaus: INPA. p. 363-374.

NIKINMAA, M., 2002. Oxygen-dependent cellular functions why fishes and their aquatic environment are a prime choice of study. Comp. Biochem. Physiol. A, vol. 133, no.1, p. 1-16.

PERRY, SF. and McDONALD, G., 1993. Gas exchange. In Evans, DH. (Ed.). The Physiology of Fishes. Boca Raton: CRC. p. 251-278.

SUNDIN, L., 1999. Hypoxia and blood flow control in fish gills. In Val, AL. and Almeida-Val, VMF. (Eds.). Biology of Tropical Fishes. Manaus: INPA. p. 353-362.

VAL, AL., 1993. Adaptations of fishes to extreme conditions in fresh waters. In Bicudo, JEPW. (Ed.). The Vertebrate Gas Transport Cascade. Adaptations to Environment and Mode of Life. Boca Raton: CRC. p. 43-53.

-, 1996. Surviving low oxygen levels: lessons from fishes of the Amazon. In Val, AL., Almeida-Val, VMF. and Randall, DJ. (Eds.). Physiology and Biochemistry of the Fishes of the Amazon. Manaus: INPA. p. 59-73.

VAL, AL. and ALMEIDA-VAL, VMF., 1995. Fishes of the Amazon and Their Environment. Physiological and Biochemical Aspects. Heidelberg: Springer. 224 p.

XU, J., LIU, Y., CUI, S. and MIAO, X., 2006. Behavioral responses of tilapia (Oreochromis niloticus) to acute fluctuations in dissolved oxygen levels as monitored by computer vision. Aquac. Engin., vol. 35, no. 3, p. 207-217.

WOOD, CM., WILSON, RW., GONZALEZ, RJ., PATRICK, HML., BERGMAN, L., NARAHARA, A. and VAL, AL., 1998. Responses of an Amazonian teleost, the tambaqui (Colossoma macropomum), to low $\mathrm{pH}$ in extremely soft water. Physiol. Zool., vol. 71, no. 6, p. 658-670.

ZALL, DM., FISHER, MD. and GARNER, QM., 1956. Photometric determination of chlorides in water. Analyt. Chem. vol. 28 , p. 1665-1678. 